\title{
Neuropathic Pain-Like Behavior after Brachial Plexus Avulsion in Mice: The Relevance of Kinin $B_{1}$ and $B_{2}$ Receptors
}

\author{
Nara L. M. Quintão, ${ }^{1}$ Giselle F. Passos, ${ }^{1}$ Rodrigo Medeiros, ${ }^{1}$ Ana F. Paszcuk, ${ }^{1}$ Fabiana L. Motta, ${ }^{3}$ João B. Pesquero, ${ }^{3}$ \\ Maria M. Campos, ${ }^{2}$ and João B. Calixto ${ }^{1}$ \\ ${ }^{1}$ Department of Pharmacology, Center of Biological Sciences, Universidade Federal de Santa Catarina, CEP 88049-900, Florianópolis, Brazil, ${ }^{2}$ School of \\ Dentistry, Pontifícia Universidade Católica do Rio Grande do Sul, CEP 90169-900 Porto Alegre, Brazil, and 32Department of Biophysics, Universidade Federal \\ de São Paulo-Escola Paulista de Medicina, CEP 04023-900 São Paulo, Brazil
}

The relevance of kinin $B_{1}\left(B_{1} R\right)$ and $B_{2}\left(B_{2} R\right)$ receptors in the brachial plexus avulsion (BPA) model was evaluated in mice, by means of genetic and pharmacological tools. BPA-induced hypernociception was absent in $B_{1} R$, but not in $B_{2} R$, knock-out mice. Local or intraperitoneal administration of the $\mathrm{B}_{2} \mathrm{R}$ antagonist Hoe 140 failed to affect $\mathrm{BPA}$-induced mechanical hypernociception. Interestingly, local or intraperitoneal treatment with $B_{1} R$ antagonists, R-715 or SSR240612, dosed at the time of surgery, significantly reduced BPA-evoked mechanical hypernociception. Intrathecal or intracerebroventricular administration of these antagonists, at the surgery moment, did not prevent the hypernociception. Both antagonists, dosed by intraperitoneal or intrathecal routes (but not intracerebroventricularly) $4 \mathrm{~d}$ after the surgery, significantly inhibited the mechanical hypernociception. At $30 \mathrm{~d}$ after the BPA, only the intracerebroventricular treatment effectively reduced the hypernociception. A marked increase in $B_{1} R$ mRNA was observed in the hypothalamus, hippocampus, thalamus, and cortex at $4 \mathrm{~d}$ after BPA and only in the hypothalamus and cortex at $30 \mathrm{~d}$. In the spinal cord, a slight increase in $\mathrm{B}_{1} \mathrm{R}$ mRNA expression was observed as early as at $2 \mathrm{~d}$. Finally, an enhancement of $\mathrm{B}_{1} \mathrm{R}$ protein expression was found in all the analyzed brain structures at 4 and $30 \mathrm{~d}$ after the BPA, whereas in the spinal cord, this parameter was augmented only at $4 \mathrm{~d}$. The data provide new evidence on the role of peripheral and central kinin $B_{1} R$ in the BPA model of neuropathic pain. Selective $B_{1} R$ antagonists might well represent valuable tools for the management of neuropathic pain.

Key words: mouse brachial plexus; neuropathic pain; hypernociception; kinins; $\mathrm{B}_{1}$ receptor; $\mathrm{B}_{2}$ receptor

\section{Introduction}

Nerve injury caused by trauma, surgery, or certain pathological states frequently leads to the development of neuropathic pain, a chronic condition that involves sensory abnormalities, including stimulus-independent persistent pain or abnormal sensory perception such as hyperalgesia (exaggerated pain sensations as a result of exposure to mildly noxious stimuli) and allodynia (pain perception on exposure to innocuous tactile stimuli) (Woolf and Mannion, 1999; Ueda and Inoue, 2001). The precise mechanisms underlying neuropathic pain and the relationship among these mechanisms, together with the signs and symptoms exhibited in

Received Sept. 25, 2007; revised Jan. 30, 2008; accepted Jan. 31, 2008.

This work was supported by grants from the Conselho Nacional de Desenvolvimento Científico e Tecnológico (CNPq), the Fundação de Apoio a Pesquisa Científica e Tecnológica do Estado de Santa Catarina, and the Programa de Apoio aos Núcleos de Excelência, Brazil. N.L.M.Q., G.F.P., A.F.P., and R.M. were supported by grants from CNPq. N.L.M.Q. and G.F.P. are PhD students, and A.F.P. is an MSc student in Pharmacology. R.M holds a postdoctoral fellowship from CNPq.

Correspondence should be addressed to Dr.J. B. Calixto, Departamento de Farmacologia, Universidade Federal de Santa Catarina, Campus Universitário, Trindade, Bloco D, CCB, Caixa Postal 476, CEP 88049-900, Florianópolis, SC, Brazil. E-mail: calixto@farmaco.ufsc.br or calixto3@terra.com.br.

N. L. M. Quintão's present address: Mestrado em Ciências Farmacêuticas, Universidade do Vale do Itajaí, Itajaí, SC, Brazil. E-mail: narafarmaco@yahoo.com.br.

DOI:10.1523/JNEUROSCI.4389-07.2008

Copyright $\odot 2008$ Society for Neuroscience $\quad$ 0270-6474/08/282856-08\$15.00/0 patients, are not fully understood. Because of this complexity, this pathological state is currently one of the most difficult conditions to treat in clinics (Gordon and Love, 2004).

Peripheral nerve injury is commonly accompanied by local inflammation characterized by the release of pronociceptive mediators such as cytokines, neurotrophins, eicosanoids, and kinins (Bennett, 1999; Cahill et al., 2003; Sah et al., 2003; Marchand et al., 2005). Bradykinin is among the most potent endogenous algogen peptides, and its role in nociceptive processes has been reviewed extensively (Dray and Perkins, 1997; Calixto et al., 2000, 2001; Couture et al., 2001). Most kinin effects are mediated by the activation of two G-protein-coupled receptors named $B_{1}\left(B_{1} R\right)$ and $B_{2}\left(B_{2} R\right)$. The $B_{2}$ Rs are constitutively expressed, and they are probably involved in the acute phase of inflammatory and nociceptive responses. In contrast, $\mathrm{B}_{1} \mathrm{Rs}$ are usually absent in intact tissues and are upregulated during tissue injury. Therefore, they might represent important players in the chronic phase of pain (Couture et al., 2001; Rashid et al., 2004; Leeb-Lundberg et al., 2005; Wang et al., 2005). Recent literature data have implicated kinin $B_{1} R$ in neuropathic pain mechanisms. For instance, increased levels of $B_{1} R$ mRNA or protein have been detected in the dorsal root ganglion (DRG) after sciatic nerve constriction injury in rodents (Petersen et al., 1998; Rashid et al., 2004). In addition, 
the systemic administration of $\mathrm{B}_{1} \mathrm{R}$ antagonist des-Arg ${ }^{9}$ $\mathrm{Leu}^{8}$-BK was able to reduce thermal and mechanical hypernociception induced by sciatic nerve constriction in rats (Levy and Zochodne, 2000; Yamaguchi-Sase et al., 2003). Interestingly, the gene deletion of $\mathrm{B}_{1} \mathrm{R}$ practically abolished the hypernociception produced by sciatic nerve injury in mice (Ferreira et al., 2005).

Neuropathic pain caused by brachial plexus avulsion (BPA) in humans has important features such as systemic mechanical and thermal hyperalgesia, which appears immediately after the injury and produces long-lasting pain behavior (Anand and Birch, 2002). This nerve lesion may trigger a pathological plasticity of the CNS, which might be responsible for the sensory alterations mentioned above (Carvalho et al., 1997). This model of neuropathic pain was originally described for rats (Rodrigues-Filho et al., 2003), and it has recently been adapted to mice (Quintão et al., 2006, 2007). In the present study, we aimed at investigating the contribution of kinin $\mathrm{B}_{1} \mathrm{R}$ and $\mathrm{B}_{2} \mathrm{R}$ in the mouse model of BPA. Special attempts were given to determine how the expression of the inducible $B_{1} R$ could be altered at the periphery and both at the spinal and supra-spinal levels, over the time following BPA.

\section{Materials and Methods}

Subjects. Female Swiss, 129/J and C57BL/6 wild-type, or kinin $\mathrm{B}_{1} \mathrm{R}$ and $\mathrm{B}_{2} \mathrm{R}$ knock-out mice (20-28 g) were used throughout this study. Females were used on the basis of the literature data, which indicate that they are more susceptible to neuropathic alterations (Mogil and Chanda, 2005; Quintão et al., 2006, 2007). Animals were housed under conditions of optimum light, temperature, and humidity (12 h light/dark cycle, $22 \pm$ $1{ }^{\circ} \mathrm{C}$, under $60-80 \%$ humidity), with food and water provided ad libitum. Swiss mice were obtained from the Department of Pharmacology, Universidade Federal de Santa Catarina (UFSC; Florianópolis, Brazil). 129/J and $\mathrm{C} 57 \mathrm{BL} / 6$ wild-type or kinin $\mathrm{B}_{1} \mathrm{R}$ and $\mathrm{B}_{2} \mathrm{R}$ knock-out mice were supplied by the Department of Biophysics, Universidade Federal de São Paulo (São Paulo, Brazil). The kinin $\mathrm{B}_{1} \mathrm{R}$ and $\mathrm{B}_{2} \mathrm{R}$ knock-out mice $\left(\mathrm{B}_{1} \mathrm{R}^{-1-}\right.$ and $\left.\mathrm{B}_{2} \mathrm{R}^{-1-}\right)$ used in the present study were $129 / \mathrm{J}$ and $\mathrm{C} 57 \mathrm{BL} / 6$ inbred, respectively. Experiments were conducted in accordance with current guidelines for the care of laboratory animals and ethical guidelines for the investigation of experimental pain in conscious animals laid down by Zimmermann (1983). The Ethics Committee of UFSC approved all the experimental procedures. The number of animals and the intensity of noxious stimuli used were the minimum necessary to demonstrate consistent effects.

Surgical procedures for BPA. The BPA was performed according to the methodology described previously (Quintão et al., 2006, 2007). First, animals were anesthetized with $7 \%$ chloral hydrate $(6 \mathrm{ml} / \mathrm{kg}$, i.p.). The right brachial plexus was approached through a longitudinal incision parallel to the clavicle, running from the sternum to the axillary region $(\sim 1 \mathrm{~cm})$. The subclavian vessels were located, and the lower trunk was dissected. The lower trunks of one group of mice were extorted by traction using forceps. In the sham-operated group, the brachial plexus was exposed and dissected without any lesion to the nerve. The tissue layers were then brought together, and the skin was closed with 4.0 silk suture string (Ethicon, Edinburgh, UK).

Hindpaw withdrawal response induced by von Frey hairs. To assess the mechanical hypernociception, mice were placed individually in clear Plexiglas boxes $(9 \times 7 \times 11 \mathrm{~cm})$ on elevated wire-mesh platforms to allow access to the ventral surface of the right hindpaw. The animals were acclimatized for $30 \mathrm{~min}$ before behavioral testing. The withdrawal response frequency was measured after 10 applications (duration of $1 \mathrm{~s}$ each) of von Frey hairs (VFHs; Stoelting, Chicago, IL). Stimuli were delivered from below to the plantar surface of the right hindpaw. The $0.6 \mathrm{~g}$ VFH produces a mean withdrawal frequency of $\sim 15 \%$, which is considered to be an adequate value for the measurement of mechanical hypernociception (Quintão et al., 2005). Therefore, the $0.6 \mathrm{~g}$ VFH was used throughout this study. To determine the basal mechanical thresholds, all the animal groups were submitted to presurgical evaluation, and they were reevaluated at several time points after the surgery.
Tail withdrawal response induced by thermal stimulus (tail flick). A radiant heat analgesiometer (Tail-Flick Analgesia Meter; Albarsch, Porto Alegre, Brazil) was used to measure latencies for tail withdrawal according to the method described by D'Amour and Smith (1941). All the animals were evaluated to determine the basal thermal threshold, and then they were submitted to the surgery, as described above. The thermal hypernociception was evaluated at several intervals of time after the surgery. Twenty seconds was adopted as the maximal time of reaction to avoid possible tissue damage.

Mechanical and thermal hypernociception after BPA in kinin $B_{1} R$ and $B_{2} R$ knock-out mice. The relevance of kinin $B_{1} R$ or $B_{2} R$ for the mechanical and thermal hypernociception induced by the BPA was analyzed using kinin $B_{1} R$ and $B_{2} R_{\text {knock-out mice }}\left(B_{1} \mathrm{R}^{-1-}\right.$ and $\left.B_{2} R^{-1-}\right)$ and the corresponding wild-type mice (129/J or C57BL/6 strains, respectively). Briefly, the animals were submitted to BPA as described above, and the mechanical and thermal hypernociceptions were evaluated at several time points after the surgery. Each set of experiments used three groups: wild-type operated and sham-operated mice and $\mathrm{B}_{1} \mathrm{R}^{-1-}$ - or $\mathrm{B}_{2} \mathrm{R}^{-1-}$ operated mice.

Effect of selective kinin $B_{2} R$ antagonist on the hypernociceptive responses induced by BPA. In this set of experiments, the involvement of kinin $\mathrm{B}_{2} \mathrm{R}$ in the mechanical hypernociception induced by BPA was evaluated by treating mice with the selective $B_{2} R$ antagonist Hoe 140, at different time periods after the surgery and by different pathways of administration. Initially, operated Swiss mice were treated with the peptidic selective $B_{2} R$ antagonist Hoe 140 ( $3 \mathrm{nmol} / \mathrm{site}$, instilled locally; $50 \mathrm{nmol} / \mathrm{kg}$, s.c.), at the moment of the surgical procedures. The mechanical hypernociception was evaluated as described previously, $4 \mathrm{~d}$ after the BPA. In other experimental groups, Hoe 140 was administered systemically $4 \mathrm{~d}$ after the surgery $(50 \mathrm{nmol} / \mathrm{kg}$, s.c.). The doses of the Hoe 140 were selected from literature data (Ferreira et al., 2002, 2004). Under these schedules of treatment, Hoe 140 did not affect the basal threshold response of animals. The results obtained in treated operated mice were compared with those obtained for operated mice that had received the vehicle alone (PBS composition (in mmol/L): $137 \mathrm{NaCl}, 2.7 \mathrm{KCl}$, and 10 phosphate buffer).

Effect of selective kinin $B_{1} R$ antagonists on the hypernociceptive responses induced by BPA. The involvement of kinin $\mathrm{B}_{1} \mathrm{R}$ was further evaluated using two selective $B_{1} R$ antagonists, administered at different intervals of time and routes of administration. First, operated Swiss mice were treated with the peptidic R-715 (60 nmol/site, instilled locally; $438 \mathrm{nmol} /$ $\mathrm{kg}$, i.p.; $25 \mathrm{nmol} / \mathrm{site}$, i.t.; or $25 \mathrm{nmol} / \mathrm{site}$, i.c.v.) or the non-peptidic SSR240612 (60 nmol/site, instilled locally; $390 \mathrm{nmol} / \mathrm{kg}$, i.p.; $25 \mathrm{nmol} /$ site, i.t.; or $25 \mathrm{nmol} /$ site, i.c.v.) $\mathrm{B}_{1} \mathrm{R}$ antagonists, given at the time of surgery. The mechanical hypernociception was evaluated as described previously, $4 \mathrm{~d}$ after the BPA.

In another set of experiments, the operated Swiss mice received R-715 ( $438 \mathrm{nmol} / \mathrm{kg}$, i.p.; $25 \mathrm{nmol} /$ site, i.t.; or $25 \mathrm{nmol} /$ site, i.c.v.) or SSR 240612 ( $390 \mathrm{nmol} / \mathrm{kg}$, i.p.; $25 \mathrm{nmol} /$ site, i.t.; or $25 \mathrm{nmol} /$ site, i.c.v.), administered $4 \mathrm{~d}$ after the surgery. To gain further insights into the profile of action of the $B_{1} R$ antagonists, the animals that had received the antagonists by intrathecal or intracerebroventricular routes on the fourth day after the BPA also received another dose on the 10th day after the surgery.

Additional groups of operated Swiss mice were treated with R-715 ( $438 \mathrm{nmol} / \mathrm{kg}$, i.p.; $25 \mathrm{nmol} /$ site, i.t.; or $25 \mathrm{nmol} /$ site, i.c.v.) or SSR240612 (390 nmol/kg, i.p.; $25 \mathrm{nmol} /$ site, i.t.; or $25 \mathrm{nmol} /$ site, i.c.v.), administered $30 \mathrm{~d}$ after the surgery. The mechanical hypernociception was evaluated as described previously at different intervals of time after the drug treatment.

The doses of the R-715 and SSR240612 were selected on the basis of literature data or pilot experiments (Gobeil et al., 1996; Fernandes et al., 2003; Gougat et al., 2004). Under these protocols of treatment, neither the R-715 nor the SSR240612 altered the basal threshold response of animals. The results obtained for treated operated mice were compared with those obtained for operated mice that had received vehicle only (PBS).

General drug administration procedures. For the local administration, $\mathrm{B}_{1} \mathrm{R}$ or $\mathrm{B}_{2} \mathrm{R}$ antagonists were dropped directly into the wound or, more exactly, they were administered onto the exposed plexus immediately after the surgery (Lindenlaub et al., 2000; Sommer et al., 2001; Quintão et 
al., 2007). The intrathecal injections were performed in conscious animals to avoid possible anesthetic interference, according to the method described by Hylden and Wilcox (1980) with some modifications. The needle connected to a microsyringe by a polyethylene tubing was introduced through the skin, and a volume of $5 \mu$ l of PBS solution alone (control) or containing the drugs was injected between the L5 and L6 vertebral spaces. For intracerebroventricular injections, the animals were slightly anesthetized with ether, and a volume of $5 \mu$ l of sterile PBS containing the drugs was injected directly into the lateral ventricle (coordinates from bregma: $1 \mathrm{~mm}$ lateral; $1 \mathrm{~mm}$ rostral; $3 \mathrm{~mm}$ vertical) as described previously by Laursen and Belknap (1986).

Expression of $B_{1} m R N A$. The expression of $B_{1} R$ mRNA was measured using reverse transcription (RT)-PCR assay, as described previously by Passos et al. (2004), with some modifications. Separate groups of operated and sham-operated mice were killed on the 2nd, 4th, or 30th day after surgery. After the mice were killed, the spinal cord and different brain structures (hypothalamus, thalamus, hippocampus, and cortex) were isolated, dissected, and frozen under liquid nitrogen and stored at $-80^{\circ} \mathrm{C}$. Thawed tissue was homogenized, and total RNA was extracted using TRIzol reagent (Invitrogen, Carlsbad, CA). Two micrograms of total RNA were reverse transcribed using oligo $(\mathrm{dT})$ as a primer $(0.05 \mu \mathrm{g})$, $50 \mathrm{U}$ of reverse transcriptase (Promega, Madison, WI), dNTP (144 $\mu \mathrm{M}$; Promega), reaction buffer [10 mM dithiothreitol (DTT), $3 \mathrm{~mm} \mathrm{MgCl}_{2}, 75$ $\mathrm{mm} \mathrm{KCl}$, and $50 \mathrm{~mm}$ Tris- $\mathrm{HCl}, \mathrm{pH}$ 8.3], and $2 \mathrm{U}$ of RNAsin Plus (Promega) in a final volume of $12.5 \mu$ l. The cDNA was obtained after incubation of the samples for $5 \mathrm{~min}$ at $70^{\circ} \mathrm{C}, 4^{\circ} \mathrm{C}$ for $5 \mathrm{~min}, 37^{\circ} \mathrm{C}$ for $60 \mathrm{~min}$, $70^{\circ} \mathrm{C}$ for $5 \mathrm{~min}$, and $4^{\circ} \mathrm{C}$ for $5 \mathrm{~min}$. The cDNA amplification of specific sequences for $B_{1} R$ and $\beta$-actin of mice was performed using the following primers: $B_{1} R$, sense AACCGTTTCAACTGGCCC and antisense GACATAAATCAGTGGGTTC; $\beta$-actin, sense TCCTTCGTTGCCGGTCCACA and antisense CGTCTCCGGAGTCCATCACA. $\beta$-Actin cDNA was used for standardization of the amount of RNA. Aliquots of $2 \mu \mathrm{l}$ of reverse transcriptase were mixed in a buffer containing $10 \mathrm{~mm}$ Tris- $\mathrm{HCl}$, pH 9, $1 \mathrm{~mm} \mathrm{MgCl}_{2}, 200 \mu \mathrm{M}$ dNTP, $300 \mathrm{~nm}$ of each primer, and $5 \mathrm{U}$ of Taq polymerase (Ludwig Biotec, Porto Alegre, Brazil) in a final volume of 30 $\mu 1$. The PCR cycling protocols were as follows: $4 \mathrm{~min}$ at $94^{\circ} \mathrm{C}, 35$ cycles of $45 \mathrm{~s}$ at $94^{\circ} \mathrm{C}, 45 \mathrm{~s}$ at $53^{\circ} \mathrm{C}$ for $\mathrm{B}_{1} \mathrm{R}$, or $45 \mathrm{~s}$ at $62^{\circ} \mathrm{C}$ for $\beta$-actin, $60 \mathrm{~s}$ at $72^{\circ} \mathrm{C}$, and finally, $5 \mathrm{~min}$ at $72^{\circ} \mathrm{C}$. Aliquots of $5 \mu \mathrm{l}$ of each sample were analyzed on a $6 \%$ Tris/borate/EDTA-polyacrylamide gel stained with silver nitrate. The size of the product was $609 \mathrm{bp}$ for $\mathrm{B}_{1} \mathrm{R}$ and $509 \mathrm{bp}$ for $\beta$-actin.

Western blot studies. Protein extraction was performed as described previously (Ferreira et al., 2005; Medeiros et al., 2007) with minor modifications. In brief, tissues were homogenized in ice-cold $10 \mathrm{~mm}$ HEPES, $\mathrm{pH} 7.4$, containing $1.5 \mathrm{~mm} \mathrm{MgCl}_{2}, 10 \mathrm{~mm} \mathrm{KCl}, 1 \mathrm{~mm}$ phenylmethylsulphonyl fluoride, $5 \mu \mathrm{g} / \mathrm{ml}$ leupeptin, $5 \mu \mathrm{g} / \mathrm{ml}$ pepstatin A, $10 \mu \mathrm{g} / \mathrm{ml}$ aprotinin, $1 \mathrm{~mm}$ sodium orthovanadate, $10 \mathrm{~mm} \beta$-glycerophosphate, $50 \mathrm{~mm}$ sodium fluoride, and 0.5 mm DTT (all from Sigma-Aldrich, São Paulo, Brazil). The homogenates were chilled on ice and vigorously shaken for $15 \mathrm{~min}$ in the presence of $1 \%$ Triton X-100. The debris was precipitated by centrifugation at $14,000 \mathrm{rpm}$ for $60 \mathrm{~min}$ at $4^{\circ} \mathrm{C}$. The supernatant was aliquoted and stored at $-70^{\circ} \mathrm{C}$ until use. Protein concentration was determined using the Bio-Rad (Hercules, CA) protein assay kit. Equal protein amounts were separated on SDS-PAGE and transferred to a polyvinylidene fluoride membrane (Immobilon P; Millipore, Bedford, MA). The membranes were saturated by incubation with $10 \%$ nonfat dry milk solution and incubated overnight with one of the following antibodies: $\beta$-actin or bradykinin $\mathrm{B}_{1} \mathrm{R}$ (both from Santa Cruz Biotechnology, Santa Cruz, CA). After washing, the membranes were incubated with adjusted secondary antibodies coupled to alkaline phosphatase. The immunocomplexes were visualized using the BCIP/NBT (5-bromo-4-chloro-3indolyl phosphate/nitro blue tetrazolium) color development substrate (Promega). Band density measurements were made using Scion (Frederick, MD) Image software package.

Drugs and reagents. The following drugs and reagents were used: PBS tablets and Tris (Sigma, St. Louis, MO); chloral hydrate (Vetec, Rio de Janeiro, Brazil); R-175, kindly provided by Dr. D. Regoli (University of Sherbrooke, Sherbrooke, Quebec, Canada); SSR240612 and Hoe 140 (Icatibant), kindly provided by Sanofi-Synthelabo and by Aventis, respectively (currently Sanofi-Aventis, Bridgewater, NJ). The stock solu-

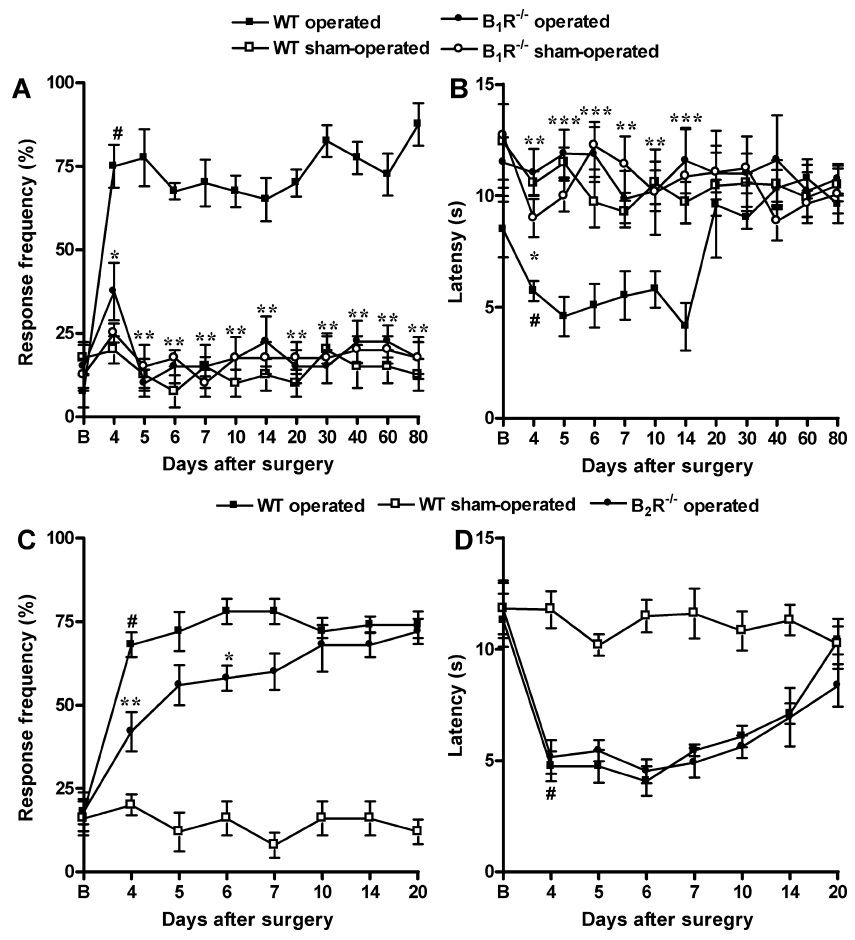

Figure 1. Hypernociceptive responses induced by $B P A$ in $B_{1} R^{-/-}$and $B_{2} R^{-1-}$ mice. Mechanical $(\boldsymbol{A}, \boldsymbol{C})$ and thermal $(\boldsymbol{B}, \boldsymbol{D})$ threshold of $B_{1} R^{-1-}$ and $B_{2} R^{-1-}$ mice, wild-type (WT) operated mice, and sham operated mice evaluated at different time intervals after BPA. Each group represents the mean of four to six animals, and the error bars indicate the SEM. ${ }^{*} p<$ $0.05,{ }^{* *} p<0.01$, and ${ }^{* * *} p<0.001$, significantly different from wild-type operated mice; \#, significantly different from wild-type sham-operated mice values. B, Baseline withdrawal threshold.

tions of the drugs were prepared in PBS in siliconized plastic tubes, maintained at $-18^{\circ} \mathrm{C}$, and diluted to the desired concentration just before use.

Statistical analysis. Results are presented as the mean \pm SEM of four to six animals for each experimental group. The percentages of inhibition are reported as the difference (in percentage) between the areas under the time-response curve of the test group in relation to the corresponding control group. The statistical comparison between these values was performed by one-way ANOVA followed by the Newman-Keuls post hoc test. Statistical comparison of the data were performed by two-way ANOVA followed by Bonferroni's post-test. $p$ values $<0.05$ were considered significant.

\section{Results}

The results in Figure 1 demonstrate that BPA induces a significant decrease in both mechanical and thermal withdrawal threshold in wild-type (both 129/J and C57BL/6 strains) mice compared with a sham-operated group, in a manner essentially similar to that described for Swiss mice (Quintão et al., 2006, 2007). When $B_{1} R^{-1-}$ mice were submitted to the BPA, both mechanical and thermal hypernociceptive responses were almost completely abolished $(p<0.001)$ during the entire period of evaluation (80 d after surgery) (Fig. $1 A, B$ ). However, when $\mathrm{B}_{2} \mathrm{R}$ ${ }^{-1-}$ mice were submitted to this surgery, a partial reduction in mechanical hypernociception was observed, but only at the initial time points after BPA (4-6 d after; inhibition of $26 \pm 7 \%$ ), whereas thermal hypernociception remained unaffected compared with corresponding wild-type mice (Fig. 1C,D),

The participation of kinin $\mathrm{B}_{2} \mathrm{R}$ in the mechanical hypernociception induced by BPA in mice was further investigated by using the selective $B_{2} R$ antagonist Hoe 140 . The results presented in 

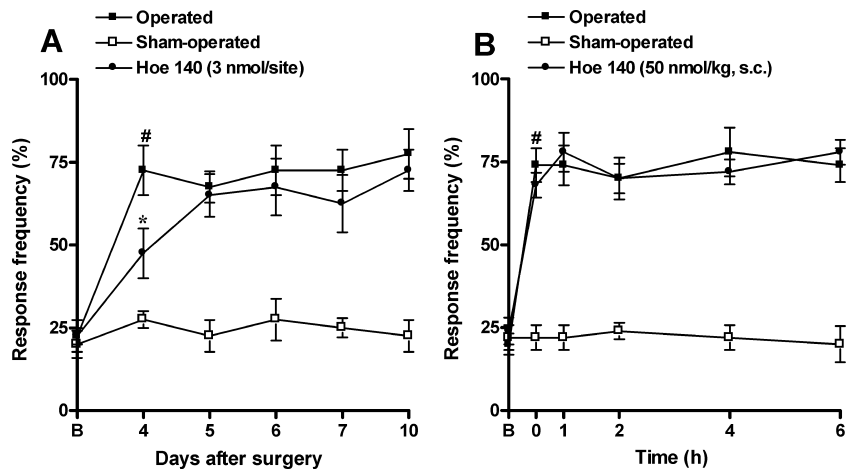

Figure 2. Effects of treatment with the $B_{2} R$-selective antagonist Hoe 140 on mechanical hypernociception induced by BPA in mice. The effect of the treatment with Hoe 140 locally (3 $\mathrm{nmol} / \mathrm{site} ; \boldsymbol{A})$ at the moment of surgery or systemically $(50 \mathrm{nmol} / \mathrm{kg}$, s.c.; $\boldsymbol{B}) 4 \mathrm{~d}$ after on mechanical hypernociception induced by BPA in mice is shown. Each group represents the mean of four to six animals, and the error bars indicate the SEM. ${ }^{*} p<0.05$, significantly different from the operated group; \#, significantly different from the sham-operated group. B, Baseline withdrawal threshold.
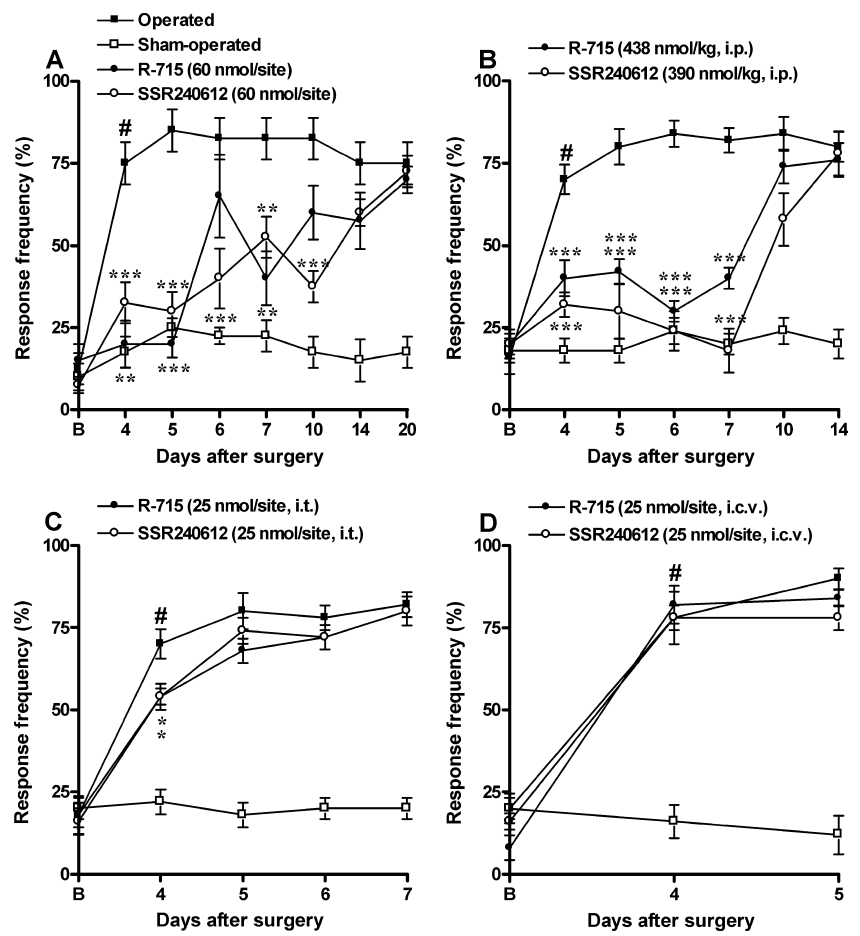

Figure 3. Effects of treatment with $B_{1} R$-selective antagonists, administered at the moment of surgery, on mechanical hypernociception induced by BPA in mice. The effects of local $(\boldsymbol{A})$, intraperitoneal $(\boldsymbol{B})$, intrathecal $(\boldsymbol{C})$, or intracerebroventricular $(\boldsymbol{D})$ treatment with R-715 or SSR240612, administered at the moment of surgery, on mechanical hypernociception induced by BPA in mice are shown. Each group represents the mean of four to six animals, and the error bars indicate the SEM. ${ }^{*} p<0.05,{ }^{* *} p<0.01$, and ${ }^{* * *} p<0.001$, significantly different from the operated group; \#, significantly different from the sham-operated group. B, Baseline withdrawal threshold.

Figure 2 demonstrate that neither the local nor the systemic administration of Hoe 140 (3 nmol/site and $50 \mathrm{nmol} / \mathrm{kg}$, s.c., respectively) was able to significantly reduce the mechanical hypernociception induced by BPA when dosed at the time of the surgery or $4 \mathrm{~d}$ after.

As can be seen in Figure $3 A$, the selective kinin $B_{1} R$ antagonists R-715 and SSR240612 (both $60 \mathrm{nmol} /$ site) administered locally at the time of surgery were able to prevent the mechanical hyperno- ciception for up to $10 \mathrm{~d}$ thereafter, with inhibitions of $57 \pm 5$ and $59 \pm 2 \%$, respectively. When R-715 (438 nmol/kg, i.p.) or SSR240612 (390 nmol/kg, i.p.) was administered systemically at the time of the surgery, both of them were capable of significantly preventing the mechanical hypernociception for up to $7 \mathrm{~d}$ after the BPA, with inhibitions of $53 \pm 2$ and $67 \pm 5 \%$, respectively (Fig. 3B). In contrast, the administration of R-715 or SSR240612 $(25 \mathrm{nmol} / \mathrm{site})$ at the time of surgery, by either the intrathecal or intracerebroventricular route, failed to significantly affect the mechanical hypernociception induced by BPA (Fig. 3C,D).

In an attempt to further evaluate the involvement of kinin $B_{1} R$ in the maintenance of mechanical hypernociception induced by BPA, operated mice were treated by different routes of administration $4 \mathrm{~d}$ after the surgical procedure. The results depicted in Figure $4 A$ demonstrate that systemic treatment with R-715 (438 $\mathrm{nmol} / \mathrm{kg}$, i.p.) or SSR240612 (390 nmol/kg, i.p.) was effective in inhibiting the mechanical hypernociception for up to $2 \mathrm{~h}$ after drug administration, with inhibitions of $32 \pm 2$ and $51 \pm 4 \%$, respectively. The administration of R-715 or SSR240612 (25 $\mathrm{nmol} /$ site), by the intrathecal route, markedly inhibited the mechanical hypernociception for up to $6 \mathrm{~h}$ after the treatment (inhibitions of $62 \pm 4$ and $67 \pm 6 \%$, respectively). Nevertheless, when the same group of mice received an additional intrathecal dose of R-715 or SSR240612, $10 \mathrm{~d}$ after BPA, the inhibitory effects of the antagonists were observed for up to $2 \mathrm{~h}$ after (inhibitions of $36 \pm 4$ and $53 \pm 4 \%$, respectively) (Fig. $4 B$ ). Interestingly, the intracerebroventricular treatment with R-715 or SSR240612 (25 $\mathrm{nmol} / \mathrm{site}$ ) on the fourth day after BPA was able to significantly reduce the mechanical hypernociception induced by BPA, but only for $30 \mathrm{~min}$ after the treatment (inhibition of $23 \pm 5$ and $21 \pm$ $4 \%$, respectively). However, when mice received a second injection of the antagonists $10 \mathrm{~d}$ after the surgery, the inhibitory effects were observed for up to $4 \mathrm{~h}$ after the drug administration, with inhibitions of $47 \pm 2$ and $61 \pm 3 \%$, respectively (Fig. $4 C$ ).

To assess how $B_{1} R$ might contribute to the long-term profile of mechanical hypernociception induced by BPA, different groups of mice received the antagonists $30 \mathrm{~d}$ after surgery. Figure $4 D$ demonstrates that both $\mathrm{R}-715$ (438 nmol/kg, i.p.) and SSR240612 (390 nmol/kg, i.p.) failed to significantly alter the mechanical hypernociception induced by BPA, when administered $30 \mathrm{~d}$ after surgery. As can be observed in Figure $4 E$, intrathecal treatment with R-715 (25 nmol/site), but not SSR240612 ( $25 \mathrm{nmol} /$ site), significantly inhibited the mechanical hypernociception for a mere $30 \mathrm{~min}$ after the treatment (inhibition of $12 \pm$ $2 \%)$. However, when the antagonists were dosed by the intracerebroventricular route (Fig. $4 F$ ), the mechanical hypernociception was markedly inhibited for up to $6 \mathrm{~h}$ after the drug administration (59 \pm 2 and $66 \pm 5 \%$, respectively). We applied statistical analysis to confirm how the effects of the antagonists might be significantly different, depending on the time and on the route of administration. This set of results is depicted in Figure 5 .

To evaluate the effects of BPA on the expression of kinin $B_{1} R$ in some of the central structures, both the mRNA and the protein expression of this receptor were evaluated in Swiss mice, by means of RT-PCR and Western blot experimental protocols, respectively. As demonstrated in Figures 6 and 7, a basal kinin $B_{1} R$ mRNA and protein expression was detected in all structures obtained from sham-operated mice. Notably, an expressive enhancement of kinin $B_{1} R$ mRNA was observed in the spinal cord (collected $2 \mathrm{~d}$ after the surgery) (Fig. 6A); the hypothalamus, hippocampus, thalamus and cortex (collected $4 \mathrm{~d}$ after surgery) (Fig. 6B); and the hypothalamus and cortex (collected $30 \mathrm{~d}$ after 
the BPA) (Fig. 6C) of operated animals compared with sham-operated mice. Furthermore, the $B_{1}$ protein expression was found increased in the spinal cord at $4 \mathrm{~d}$ and in the hypothalamus, hippocampus, thalamus, and cortex at 4 and $30 \mathrm{~d}$ after the surgery (Fig. 7).

\section{Discussion}

We recently reported the relevance of the cytokine tumor necrosis factor- $\alpha$ (TNF $\alpha)$ and neurotrophic factors, namely nerve growth factor (NGF), glial cell line-derived neurotrophic factor (GDNF), brain-derived neurotrophic factor, and neurotrophin-3, in the hypernociception induced by BPA in mice (Quintão et al., 2006, 2007). Evidence points out kinin $B_{1} R$ and $B_{2} R$ as new targets for the actions of TNF $\alpha$ during peripheral nerve injury (Leeb-Lundberg et al., 2005). Lee et al. (2002) have reported that NGF is involved in the upregulation of $\mathrm{B}_{2} \mathrm{R}$ after peripheral nerve injury. Additional studies on DRG culture cells have demonstrated that GDNF upregulates $B_{1} R$ in $\sim 20 \%$ of a total neuronal population (Vellani et al., 2004). The authors suggest that GDNF released by cells of neighboring tissues, together with inflammatory cells, might act on injured peripheral neurons, modulating the expression of $\mathrm{B}_{1} \mathrm{R}$. Following these lines of evidence, we decided to analyze the relevance of kinin $B_{1} R$ and $B_{2} R$ in the hypernociceptive responses after BPA in mice. We provide evidence implicating the $B_{1} R$ but not $B_{2} R$ subtype in the nociceptive changes observed in the mouse BPA model. The great novelty of this study is supported by demonstrating that $\mathrm{B}_{1} \mathrm{R}$ might be distinctly upregulated at the periphery and the spinal and supra-spinal levels, according to the interval of time following BPA. Our data suggest, for the first time, that temporal and regional differences in the expression of kinin $\mathrm{B}_{1} \mathrm{R}$ could be related to the long-lasting profile of hypernociception observed in BPA.

The role of kinins in mediating nociception has been well established (Calixto et al., 2000, 2001, 2004; Pesquero et al., 2000; Ferreira et al., 2005; Leeb-Lundberg et al., 2005; Campos et al., 2006). Walker et al. (1995) affirmed the existence of the kinin system components throughout the CNS. Petersen et al. (1998) demonstrated that, after partial sciatic nerve ligation (PSNL) or axotomy, there are marked changes in the expression of kinin receptors in DRG neurons. In addition, reasonable concentrations of bradykinin, and a moderate density of kinin receptors, have been described in the spinal cord, cerebellum, cortex, and hippocampus, justifying the involvement of kinins in pain control (Kariya et al., 1985; Fujiwara et al., 1989; Couture and Lindsey, 2000). $\mathrm{B}_{2} \mathrm{R}$ activation has been extensively related with the initial phase of inflammatory pain, whereas $B_{1} R$ stimulation has been associated with long-lasting alterations. Rashid et al. (2004) demonstrated the occurrence of de novo synthesis of $B_{1} R$ after PSNL, mainly at large-diameter myelinated
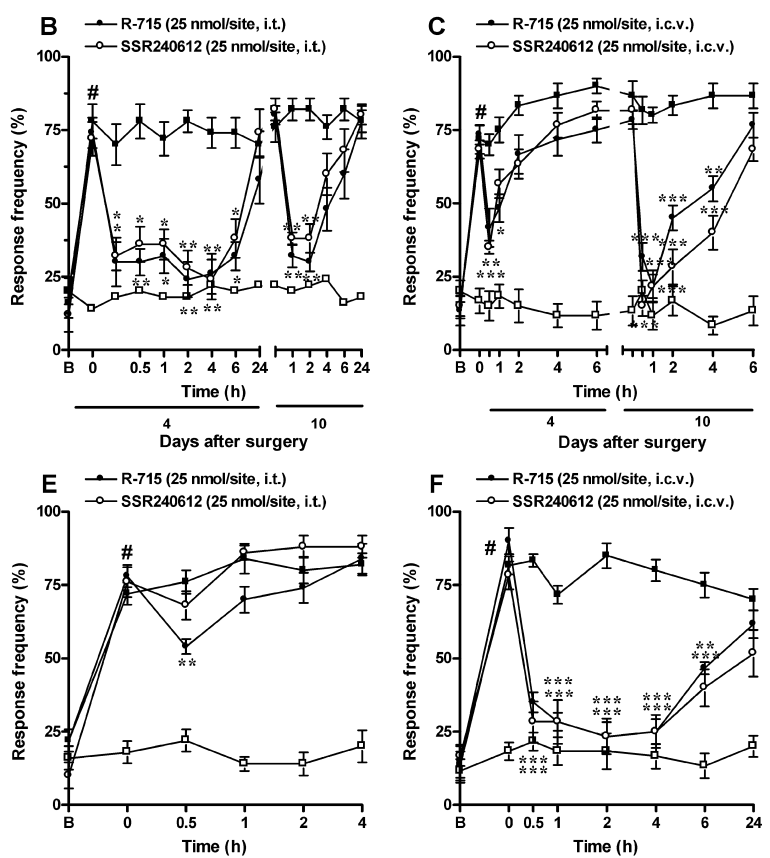

Figure 4. Effects of treatment with $B_{1} R$-selective antagonists, administered on the 4th and 30th days after surgery, on mechanical hypernociception induced by BPA in mice. The effects of intraperitoneal $(\boldsymbol{A}, \boldsymbol{D})$, intrathecal $(\boldsymbol{B}, \boldsymbol{E})$, or intracerebrovenmechanical hypernociception induced by BPA in mice. Exceptionally, for intrathecal and intracerebroventricular treatments, mice were retreated $10 \mathrm{~d}$ after the surgery. Each group represents the mean of four to six animals, and the error bars indicate the SEM. ${ }^{*} p<0.05,{ }^{* *} p<0.01$, and ${ }^{* * *} p<0.001$, significantly different from the operated group; \#, significantly different from the
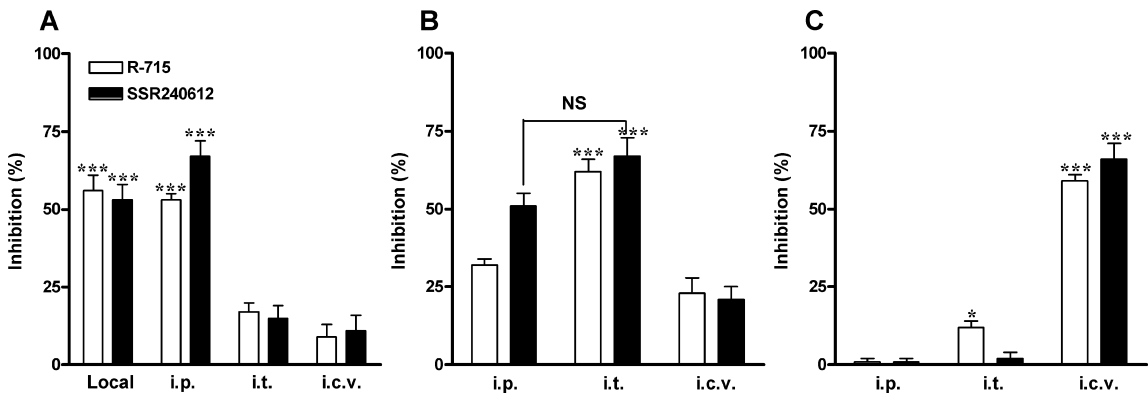

Figure 5. Comparison among the percentages of inhibition observed after treatment with the selective $B_{1} R$ antagonists by different pathways of administration, at distinct intervals of time. Percentages of inhibition of R-715 or SSR241612, when administered locally, intraperitoneally, intrathecally, or intracerebroventricularly at the moment of surgery $(\boldsymbol{A})$, on the 4th day $(B)$, or on the $30^{\text {th }}$ day $(\boldsymbol{C})$ after BPA, are shown. Each group represents the mean of four to six animals, and the error bars indicate the SEM. ${ }^{*} p<0.05$ and ${ }^{* * *} p<0.001$, significantly different from the operated group. NS, Not significant.

DRG neurons, whereas the $\mathrm{B}_{2} \mathrm{R}$ expression was decreased. Recently, Enquist et al. (2007) demonstrated the occurrence of a rapid $B_{2} R$ internalization after agonist exposure, followed by $B_{1} R$ induction without desensitization.

Our first set of results revealed that both mechanical and thermal hypernociceptions induced by BPA were almost completely abolished in $\mathrm{B}_{1} \mathrm{R}^{-/-}$mice, whereas genetic deletion of $\mathrm{B}_{2} \mathrm{R}$ produced only a slight reduction in the hypernociception. Rupniak et al. (1997) showed that thermal hyperalgesia induced by intraplantar injection of complete Freund's adjuvant (CFA) was not significantly altered in $\mathrm{B}_{2} \mathrm{R}^{-/-}$mice. Likewise, Ferreira et al. (2001) demonstrated that $\mathrm{B}_{2} \mathrm{R}^{-1-}$ mice presented similar hypernociceptive behavior after CFA injection, and these results were confirmed using the selective $\mathrm{B}_{2} \mathrm{R}$ antagonist Hoe 140. Another 

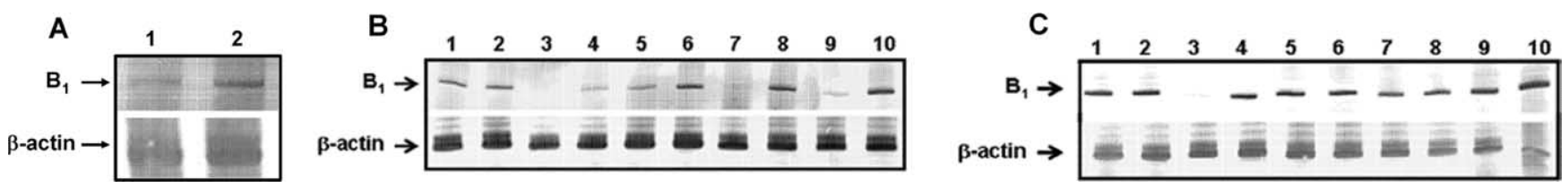

Figure 6. Evaluation of $B_{1} R$ mRNA levels in CNS structures of mice submitted to BPA. $B_{1} R$ mRNA levels in spinal and supra-spinal structures extracted from operated and sham-operated mice $2 \mathrm{~d}$ $(\boldsymbol{A}), 4 \mathrm{~d}(\boldsymbol{B})$, or $30 \mathrm{~d}(\boldsymbol{C})$ after BPA are shown. Data were normalized using respective mRNA levels for $\beta$-actin. Results were obtained with three individual experiments. Lane 1, Sham-operated spinal cord; lane 2, operated spinal cord; lane 3, sham-operated hypothalamus; lane 4, operated hypothalamus; lane 5, sham-operated hippocampus; lane 6, operated hippocampus; lane 7, shamoperated thalamus; lane 8, operated thalamus; lane 9, sham-operated cortex; lane 10, operated cortex.
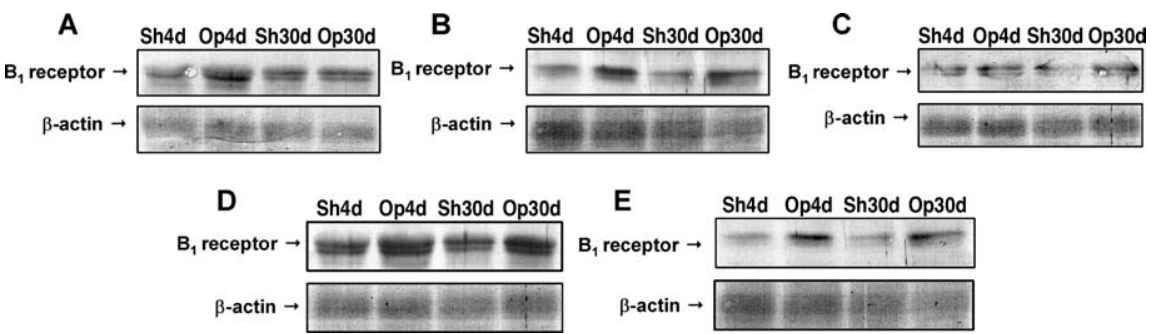

Figure 7. Evaluation of $B_{1} R$ protein expression in CNS structures of mice submitted to $B P A \cdot B_{1} R$ protein levels in spinal cord $(A)$, hypothalamus $(\boldsymbol{B})$, hippocampus $(\boldsymbol{C})$, thalamus (D), and cortex (E) extracted from sham-operated (Sh) and operated (Op) mice 4 $d(4 d)$ or $30 \mathrm{~d}(30 \mathrm{~d})$ after BPA, are shown. Data were normalized using respective protein levels for $\beta$-actin. Data represent three individual experiments.

interesting fact is that the hyperalgesic response induced by the selective $\mathrm{B}_{1} \mathrm{R}$ agonist des-Arg ${ }^{9}$-BK was greatly enhanced in $\mathrm{B}_{2} \mathrm{R}^{-1-}$ mice (Ferreira et al., 2002). In our study, $\mathrm{B}_{2} \mathrm{R}^{-1-}$ mice presented a partial, although significant, reduction in the mechanical hypernociception after BPA, an effect that was observed only at two early time points (fourth and sixth days) after surgery. However, the thermal hypernociception remained virtually unaffected in $\mathrm{B}_{2} \mathrm{R}^{-1-}$ mice. These data allow us to imply only a minor role for $\mathrm{B}_{2} \mathrm{R}$ in the hypernociceptive changes induced by BPA. Extending this notion, the administration of the selective $\mathrm{B}_{2} \mathrm{R}$ antagonist Hoe 140 , even at the moment of the surgery or $4 \mathrm{~d}$ later, failed to significantly alter the mechanical hypernociception induced by BPA. It is possible to conclude that $\mathrm{B}_{2} \mathrm{R}$ activation does not represent an essential step for the nociceptive behavioral changes observed in our model.

It has been shown that $\mathrm{B}_{1} \mathrm{R}^{-/-}$mice show hypoalgesia in chemical models of nociception, probably related with a reduction in dependent activity facilitation (wind-up) of spinal nociceptive reflexes (Pesquero et al., 2000). The present results clearly suggest that $\mathrm{B}_{1} \mathrm{R}$ has a critical role in the hypernociceptive behavior caused by BPA, as evidenced by an almost complete absence of both mechanical and thermal hypernociceptive responses in $\mathrm{B}_{1} \mathrm{R}^{-1-}$ mice. $\mathrm{Ma}$ et al. (2000) and Wotherspoon and Winter (2000) described the presence of constitutive $B_{1} R$ in rat and mouse sensory neurons, justifying the reduction in nociceptive responses in $\mathrm{B}_{1} \mathrm{R}^{-1-}$ mice at the early time points after BPA. When evaluated in a persistent inflammatory model of pain (Ferreira et al., 2001), $\mathrm{B}_{1} \mathrm{R}^{-\prime-}$ mice presented a marked reduction in ipsilateral and contralateral thermal sensitivity induced by CFA. A comparable inhibitory effect was observed using the selective $\mathrm{B}_{1} \mathrm{R}$ antagonist des-Arg ${ }^{9}$-[Leu $\left.{ }^{8}\right]$-BK (Ferreira et al., 2001). In addition, selective antagonists for $\mathrm{B}_{1} \mathrm{R}$ effectively reduce thermal hyperalgesia in streptozotocin-diabetic mice (Gabra and Sirois, $2002,2003)$. When analyzed in concert with literature data, our results reinforce the importance of $B_{1} R$ in the modulation of persistent pain.

We have in mind that knock-out animals might display some compensatory differences in relation to the corresponding wild- type strain. For example, the occurrence of a compensatory increase in $\mathrm{B}_{1} \mathrm{R}$ expression has been suggested in $\mathrm{B}_{2} \mathrm{R}^{-1-}$ mice (Madeddu et al., 1997; Duka et al., 2001). Moreover, experiments conducted in $\mathrm{B}_{1} \mathrm{R}^{-1-}$ mice do not completely permit us to define whether $\mathrm{B}_{1} \mathrm{Rs}$ are involved in the early and/or the long-term hypernociceptive changes caused by BPA. Thus, we performed additional experiments in which selective peptide (R-715) and nonpeptide (SSR240612) $B_{1} R$ antagonists were dosed by different pathways of administration, at distinct intervals of time before and after BPA. These experiments supplied very interesting data concerning the role of $B_{1} R$ under nerve injury: (1) both the local and the systemic (intraperitoneal) administration of R-715 and SSR241206 (but not the intrathecal or intracerebroventricular) significantly prevented the mechanical hypernociception induced by BPA, when dosed at the moment of the surgery; (2) both $B_{1} R$ antagonists produced a marked and long-term decrease in mechanical hypernociception induced by BPA when dosed on the fourth day by the intrathecal route; and (3) the intracerebroventricular administration of R-715 and SSR240612 on the 30th day after BPA greatly reduced the mechanical hypernociception. We might infer that peripheral $\mathrm{B}_{1}$ Rs are probably involved in the establishment of hypernociceptive alterations in this model. Alternatively, $\mathrm{B}_{1} \mathrm{R}$ might well be implicated in the maintenance of hypernociceptive processes after BPA, probably by activating spinal and supra-spinal pathways of pain control. This conclusion is reinforced by data in Figure 5, which show a statistical comparison among the percentages of inhibition after administration of $B_{1} R$ antagonists by different routes and at distinct intervals of time. It appears that $B_{1} R s$ are expressed and/or activated in a different manner depending on the period after the BPA.

Ferreira et al. (2005) demonstrated that $\mathrm{B}_{1} \mathrm{R}^{-1-}$ mice had the nociceptive hypersensitization abolished when submitted to PSNL. The authors also observed that $B_{1} R$ mRNA was significantly enhanced in mouse plantar surface tissue, sciatic nerve, and spinal cord $7 \mathrm{~d}$ after PSNL. It is reasonable to suggest that the upholding of the neuropathic state in the BPA model might be dependent on the increased $B_{1} R$ expression at central structures related to the pain control. Therefore, we assessed the levels of $\mathrm{B}_{1} \mathrm{R}$ mRNA and the protein expression in certain central structures by means of RT-PCR and Western blot experiments, respectively, at distinct time points after BPA. First, kinin $B_{1} R$ mRNA expression was slightly, but visibly, enhanced in the spinal cord of operated animals at $2 \mathrm{~d}$ after the surgery. Second, a marked increase in $B_{1} R$ mRNA was found in the hypothalamus, hippocampus, thalamus, and cortex at $4 \mathrm{~d}$ after BPA, and in the hypothalamus and cortex at $30 \mathrm{~d}$. Last, an enhancement of $B_{1} R$ 
protein expression was found in all the analyzed brain structures at 4 and $30 \mathrm{~d}$, whereas it was increased only at $4 \mathrm{~d}$ in the spinal cord. These pieces of evidence substantiate the pharmacological experiments using the intrathecal and intracerebroventricular routes for the administration of the $B_{1} R$ antagonists. Whereas both the spinal and the supra-spinal upregulation of $B_{1} R$ seems to be related to the hypernociceptive changes observed at $4 \mathrm{~d}$ after $\mathrm{BPA}$, only the supra-spinal modulation of this receptor is likely associated with the painful alterations at $30 \mathrm{~d}$ after the neuropathic lesion. Certainly, additional experiments using GTP $\gamma[\mathrm{S}]$ autoradiography to evaluate G-protein activation at central anatomical structures after $B_{1} R$ agonist stimulation might be useful to confirm the present molecular data. However, this remains to be investigated in the future.

Altogether, our results indicate a relevant role for peripheral and central kinin $B_{1} R$ (but not $B_{2} R$ ) in the mouse BPA model and call attention to the attractive potential of $B_{1} R$ as a new target for neuropathic pain management. Selective $B_{1} R$ antagonists, especially those of a nonpeptidic and orally active nature, might be useful for the control of long-lasting neuropathic states that are refractory to the currently available therapy.

\section{References}

Anand P, Birch R (2002) Restoration of sensory function and lack of longterm chronic pain syndromes after brachial plexus injury in human. Brain 125:113-122.

Bennett GJ (1999) Does a neuroimmune interaction contribute to the genesis of painful peripheral neuropathies? Proc Natl Acad Sci USA 96:7737-7738.

Cahill CM, Dray A, Coderre TJ (2003) Intrathecal nerve growth factor restores opioid effectiveness in an animal model of neuropathic pain. Neuropharmacology 45:543-552.

Calixto JB, Beirith A, Ferreira J, Santos AR, Filho VC, Yunes RA (2000) Naturally occurring antinociceptive substances from plants. Phytother Res 14:401-418.

Calixto JB, Scheidt C, Otuki MF, Santos ARS (2001) Biological activity of plant extracts: novel analgesic drug. Expert Opin Emerg Drugs 6:261-279.

Calixto JB, Medeiros R, Fernandes ES, Ferreira J, Cabrini D, Campos MM (2004) Kinin B1 receptors: key G-protein-coupled receptors and their role in inflammatory and painful processes. Br J Pharmacol 143:803-818.

Campos MM, Leal PC, Yunes RA, Calixto JB (2006) Non-peptide antagonists for kinin $\mathrm{B}(1)$ receptors: new insights into their therapeutic potential for the management of inflammation and pain. Trends Pharmacol Sci 27:646-651.

Carvalho GA, Nikkhah G, Samii M (1997) Pain management after posttraumatic brachial plexus lesions. Conservative and surgical therapy possibilities. Orthopade 26:621-625.

Couture R, Lindsey CJ (2000) Brain kallikrein-kinin system: from receptors to neuronal pathways and physiological functions. In: Handbook of chemical anatomy (Quirion R, Brörklund A, Hökfeld T, eds), pp 241-298. Amsterdam: Elsevier.

Couture R, Harrisson M, Vianna RM, Cloutier F (2001) Kinin receptors in pain and inflammation. Eur J Pharmacol 429:161-176.

D’Amour FE, Smith J (1941) A method for determining loss of pain sensation. J Pharmacol Exp Ther 72:74-79.

Dray A, Perkins M (1997) Kinins and pain. In: The handbook of immunopharmacology: the kinin system (Farmer SG, ed), pp 157-172. London: Academic.

Duka I, Kintsurashvili E, Gavras I, Johns C, Bresnahan M, Gavras H (2001) Vasoactive potential of the $\mathrm{B} 1$ bradykinin receptor in normotension and hypertension. Circ Res 88:275-281.

Enquist J, Skroder C, Whistler JL, Leeb-Lundberg LM (2007) Kinins promote $\mathrm{B} 2$ receptor endocytosis and delay constitutive B1 receptor endocytosis. Mol Pharmacol 71:494-507.

Fernandes ES, Passos GF, Campos MM, Araújo JG, Pesquero JL, Avellar MC, Teixeira MM, Calixto JB (2003) Mechanisms underlying the modulatory action of platelet activating factor (PAF) on the upregulation of kinin B1 receptors in the rat paw. Br J Pharmacol 139:973-981.

Ferreira J, Campos MM, Pesquero JB, Araújo RC, Bader M, Calixto JB (2001)
Evidence for the participation of kinins in Freund's adjuvant-induced inflammatory and nociceptive responses in kinin $\mathrm{B} 1$ and $\mathrm{B} 2$ receptor knockout mice. Neuropharmacology 41:1006-1012.

Ferreira J, Campos MM, Araújo RC, Bader M, Pesquero JB, Calixto JB (2002) The use of kinin B1 and B2 receptor knockout mice and selective antagonists to characterize the nociceptive responses caused by kinins at the spinal level. Neuropharmacology 43:1188-1197.

Ferreira J, da Silva GL, Calixto JB (2004) Contribution of vanilloid receptors to the overt nociception induced by $\mathrm{B} 2$ kinin receptor activation in mice. Br J Pharmacol 141:787-794.

Ferreira J, Beirith A, Mori MAS, Araújo RC, Bader M, Pesquero JB, Calixto JB (2005) Reduced nerve injury-induced neuropathic pain in kinin B1 receptor knock-out mice. J Neurosci 25:2405-2415.

Fujiwara Y, Mantione CR, Vavrek RJ, Stewart JM, Yamamura HI (1989) Characterization of $(3 \mathrm{H})$ bradykinin binding sites in guinea-pig central nervous system: possible existence of B2 subtypes. Life Sci 44:1645-1653.

Gabra BH, Sirois P (2002) Role of bradykinin B1 receptors in diabetesinduced hyperalgesia in streptozotocin-treated mice. Eur J Pharmacol 457:115-124.

Gabra BH, Sirois P (2003) Beneficial effects of chronic treatment with the selective bradykinin B1 receptor antagonists, R-715 and R-954, in attenuating streptozotocin-diabetic thermal hyperalgesia in mice. Peptides 24:1131-1139.

Gobeil F, Neugebauer W, Filteau C, Jukic D, Allogho SN, Pheng LH, Nguyen-Le XK, Blouin D, Regoli D (1996) Structure-activity studies of B1 receptor-related peptides. Antagonists Hypertens 28:833-839.

Gordon DB, Love G (2004) Pharmacologic management of neuropathic pain. Pain Manag Nurs 5:19-33.

Gougat J, Ferrari B, Sarran L, Planchenault C, Poncelet M, Maruani J, Alonso R, Cudennec A, Croci T, Guagnini F, Urban-Szabo K, Martinolle JJ, Soubrié P, Finance O, Le Fur G (2004) SSR240612 [(2R)-2-[((3R)-3-(1,3benzodioxol-5-yl)-3-\{[(6-methoxy-2-

naphthyl)sulfonyl]amino\}propanoyl)amino $]-3-(4-\{[2 R, 6 S)-2,6-$

dimethylpiperidinyl] methyl $\}$ phenyl)- $N$-isopropyl- $N$ -

methylpropanamide hydrochloride], a new nonpeptide antagonist of the bradykinin B1 receptor: biochemical and pharmacological characterization. J Pharmacol Exp Ther 309:661-669.

Hylden JL, Wilcox GL (1980) Intrathecal morphine in mice: a new technique. Eur J Pharmacol 67:313-316.

Kariya K, Yamaguchi A, Sasaki T (1985) Regional distribution and characterization of kinin in the CNS of the rat. J Neurochem 44:1892-1897.

Laursen SE, Belknap JK (1986) Intracerebroventricular injections in mice: some methodological refinements. J Pharmacol Methods 16:355-357.

Lee Y-J, Zachrisson O, Tonge DA, MacNaugton PA (2002) Upregulation of bradykinin $\mathrm{B} 2$ receptor expression by neurotrophic factors and nerve injury in mouse sensory neurons. Mol Cell Neurosci 19:186-200.

Leeb-Lundberg LM, Marceau F, Müller-Esterl W, Pettibone DJ, Zuraw BL (2005) International Union of Pharmacology. XLV. Classification of the kinin receptor family: from molecular mechanisms to pathophysiological consequences. Pharmacol Rev 57:27-77.

Levy D, Zochodne DW (2000) Increased mRNA expression of the B1 and B2 bradykinin receptors and antinociceptive effects of their antagonists in an animal model of neuropathic pain. Pain 86:265-271.

Lindenlaub T, Teuteberg P, Hartung T, Sommer C (2000) Effects of neutralizing antibodies to TNF-alpha on pain-related behavior and nerve regeneration in mice with chronic constriction injury. Brain Res 866:15-22.

Ma Q-P, Hill R, Sirinathsinghji D (2000) Basal expression of bradykinin B1 receptor in peripheral sensory ganglia in the rat. NeuroReport 18:4003-4005.

Madeddu P, Varoni MV, Paloma D, Emanueli C, Demonstis MP, Glorioso N, Dessi-Fulgheri P, Sarzani R, Anania V (1997) Cardiovascular phenotype of a mouse strain with disruption of bradykinin B2-receptor gene. Circulation 96:3570-3578.

Marchand F, Perretti M, McMahon SB (2005) Role of the immune system in chronic pain. Nat Rev Neurosci 6:521-532.

Medeiros R, Prediger RD, Passos GF, Pandolfo P, Duarte FS, Franco JL, Dafre AL, Di Giunta G, Figueiredo CP, Takahashi RN, Campos MM, Calixto JB (2007) Connecting TNF- $\alpha$ signaling pathways to iNOS expression in a mouse model of Alzheimer's disease: relevance for the behavioral and synaptic deficits induced by amyloid $\beta$ protein. J Neurosci 27:5394-5404.

Mogil JS, Chanda ML (2005) The case for the inclusion of female subjects in basic science studies of pain. Pain 117:1-5. 
Passos GF, Fernandes ES, Campos MM, Araújo JG, Pesquero JL, Souza GE, Avellar MC, Teixeira MM, Calixto JB (2004) Kinin B1 receptor upregulation after lipopolysaccharide administration: role of proinflammatory cytokines and neutrophil influx. J Immunol 172:1839-1847.

Pesquero JB, Araújo RC, Heppenstall PA, Stucky CL, Silva JA-JR, Walther T, Oliveira SM, Pesquero JL, Paiva AC, Calixto JB, et al. (2000) Hypoalgesia and altered inflammatory responses in mice lacking kinin B1 receptors. Proc Natl Acad Sci USA 97:8140-8145.

Petersen M, Eckert AS, Segond Von Banchet G, Heppelmann B, Klusch A, Kniffki K-D (1998) Plasticity in the expression of bradykinin binding sites in the sensory neurons after mechanical nerve injury. Neuroscience 83:949-959.

Quintão NL, Santos AR, Campos MM, Calixto JB (2008) The role of neurotrophic factors in genesis and maintenance of mechanical hypernociception after brachial plexus avulsion in mice. Pain, in press.

Quintão NLM, Medeiros R, Santos ARS, Campos MM, Calixto JB (2005) Effects of diacerhein on mechanical allodynia in inflammatory and neuropathic models of nociception in mice. Anesth Analg 101:1763-1769.

Quintão NLM, Balz D, Santos ARS, Campos MM, Calixto JB (2006) Longlasting neuropathic pain induced by brachial plexus injury in mice: role triggered by pro-inflammatory cytokine, tumour necrosis factor $\alpha$. Neuropharmacology 50:614-620.

Rashid H, Inoue M, Matsumoto M, Ueda H (2004) Switching of bradykinin-mediated nociception following partial sciatic nerve injury in mice. J Pharmacol Exp Ther 308:1158-1164.

Rodrigues-Filho R, Santos ARS, Bertelli JA, Calixto JB (2003) Avulsion injury of the rat brachial plexus triggers hyperalgesia and allodynia in the hindpaws: a new model for the study of neuropathic pain. Brain Res 982:186-194.

Rupniak NMJ, Boyce S, Webb JK, Williams AR, Carlson EJ, Hill RG,
Borkowski JA, Hess JF (1997) Effects of the bradykinin B1 receptor antagonist des-Arg9-[Leu8]-BK and genetic disruption of the B2 receptor on nociception in rats and mice. Pain 71:89-97.

Sah DW, Ossipo MH, Porreca F (2003) Neurotrophic factors as novel therapeutics for neuropathic pain. Nat Rev Drug Discov 2:460-472.

Sommer C, Lindenlaub T, Teuteberg P, Schäfers M, Hartung T, Toyka KV (2001) Anti-TNF-neutralizing antibodies reduce pain-related behavior in two different mouse models of painful mononeuropathy. Brain Res 913:86-89.

Ueda H, Inoue M (2001) Animal models and peripheral nociception tests for the study of neuropathic pain. Folia Pharmacol Jpn 188:89-95

Vellani V, Zachrisson O, McNaughton PA (2004) Functional bradykinin B1 receptors are expressed in nociceptive neurons and are up-regulated by the neurotrophin GDNF. J Physiol (Lond) 560:391-401.

Walker K, Perkins M, Dray A (1995) Kinins and kinin receptors in the nervous system. Neurochem Int 26:1-16.

Wang H, Kohno T, Amaya F, Brenner GJ, Ito N, Allchorne A, Ji RR, Woolf CJ (2005) Bradykinin produces pain hypersensitivity by potentiating spinal cord glutamatergic synaptic transmission. J Neurosci 25:7986-7992.

Woolf CJ, Mannion RJ (1999) Neuropathic pain: aetiology, symptoms, mechanisms, and management. Lancet 353:1959-1965.

Wotherspoon G, Winter J (2000) Bradykinin B1 receptor in constitutively expressed in the rat sensory nervous systems. Neurosci Lett 294:175-178.

Yamaguchi-Sase S, Hayashi I, Okamoto H, Nara Y, Matsuzaki S, Hoka S, Majima M (2003) Amelioration of hyperalgesia by kinin receptor antagonists or kininogen deficiency in chronic constriction nerve injury in rats. Inflamm Res 52:164-169.

Zimmermann M (1983) Ethical guidelines for investigations of experimental pain in conscious animals. Pain 16:109-110. 